\title{
The teaching innovation idea exploring for College football training
}

\author{
Xiaowei Di, Huhu Lian \\ Sichuan Agricultural University, Chengdu, Sichuan Province, China
}

Keywords: Colleges and universities, football, training, teaching, innovation.

\begin{abstract}
Nowadays there are many colleges and universities have set up different kinds of sports teaching, mainly in order to enhance the students' physical quality, football is a kind of these sports and a lot of colleges and universities have set up. But the traditional teaching methods, there are many shortcomings in country is advocated innovation type teaching, the teaching idea is also used in the football teaching in colleges and universities, and achieved good results, the education system in the reform, also in constant innovation. In this paper, some problems existing in college football teaching has carried on the simple analysis, and introduces the innovative teaching in college football teaching, the application of more can highlight the important role of teaching innovation.
\end{abstract}

\section{Introduction}

Football in the global rise of more than one hundred years of history, both in peacetime and war era didn't stopped the pace of its development, but in the way flexible, interesting and vigorous development. One of the most favorite sports is a contemporary college students and the important content of sports teaching in colleges and universities [1]. Football training college students' interest in sports, the basic knowledge and basic skills, can make them to master some basic knowledge of football and tactics, for the development of football sports in colleges and universities.

\section{The analysis of current situation of college football teaching present situation}

Football for hundreds of years of history, with its flexible and diverse, fun way of competition booming development, countries in the world of football originated in the game, with the progress of the society, football from the original simple game development as a kind of connotation is rich, exquisite technique, against fierce modern sports [1]. Football in containing groups and individuals is exchanges and communication, competition and cooperation, strain and innovation, and many other social and cultural value, thus to have longevity into physical culture education. But football teaching in normal colleges is basically normal competitions as the main line, with the development of competitive football too difficult, resulting in load, technology and other aspects from the characteristics of entertainment in the gym, also led to the requirements of competitive football and the students' practical need to disconnect, so that the students too tricky because fear football is not easy to master football teaching [1]. FIFA has to increase the competition fierce antagonism and view and admire a gender, the game rules, and constant revision balance of offensive and defensive football technology relatively, thereby continuously to football has brought fresh vitality, attracted more people to participate in, is widely popular in the world.

From the point of the present situation of the students, the overall performance for interest, but learning goal is not clear, different levels, and most of the college students in their $20 \mathrm{~s}$ age, have missed the superior effect of technical action learning period [1]. Football lesson teaching time is limited; a shortage of space, the student is hard to in a short period of time to master complex techniques and tactics. School teaching system is unreasonable, a single teacher's knowledge structure and teaching means, lack of interest, between technical teaching and physical exercise, it is difficult to arouse the enthusiasm of students, it is difficult to improve teaching efficiency in a relatively short time. In the process of football sports, although we made great efforts, do a lot of work, 
but we still can clearly feel the football teaching or subject to exam-oriented education. And the contradiction in the teaching atmosphere is more errands lagging behind its development level. To a certain extent, dampened the college students' enthusiasm for football, also make football in colleges and universities to carry out in a passive and embarrassing situation, the reason why there are this kind of condition that we have to make for serious analysis and in-depth thinking.

\section{The problems existing in the college football teaching}

Relatively backward teaching concepts. Pays attention to the development of the education industry in our country, including sports, art, and some other than academic education, so for some disadvantages in teaching is also very concerned about, and take effective measures to solve in time. Nowadays many college football teaching in China there are a lot of problems, including the backward of teaching ideas, this is largely influence the quality of teaching. The traditional teaching concept is given priority to with the teacher's idea, students' main body is not teaching, the teacher in the whole teaching process is dominant and students just passively accept knowledge, without thinking, so will the lack of the ability of autonomous learning and innovation, it will be for the development of football has very serious effect [2]. And the teaching idea of teaching students taught by the most just simply playing some theoretical knowledge and skills, no substantial breakthroughs, it is hard to have the enthusiasm to learn football and interest, will feel tired, in the process of learning is difficult, is not conducive to mastery of knowledge, so the teaching idea behind this problem the consequences are serious, shall take effective ways to solve.

The choice of teaching contents are reasonable enough. The choice of teaching content for the teaching quality is very important, can even play a decisive role, and many college football teaching is a teaching content selection is not reasonable [2]. Because everyone want to achieve the purpose of students' football, football foundation level and learning ability is different, if you select a single teaching content can lead to part of the students did not achieve their learning purpose, their own ability has not been improved, there were still part of the students the basic level and the ability to accept knowledge is poor, can't fully grasp the teaching contents, thus makes many students' final master of this course is very poor, it did not achieve the goal of football teaching.

Teaching mode is relatively single. Single teaching mode is a lot of the problems in curriculum teaching, this is the teacher in the teaching process is a problem. The traditional football teaching mode is the teachers teaching, explains some theoretical knowledge and practical skills, students in memory and imitation, in this process is lack of thinking, so the students know the final situation is not very good. In addition, the lack of interaction between students, the football is a collective activity course, by the mere force of individual is not able to complete, so students not only need to have basic level of knowledge and technology to play football, shall also have the spirit of solidarity and collaboration, which is one of the traditional teaching mode will not be able to achieve the teaching effect [3]. Thus, single teaching mode has not suitable for today's teaching, not only the football teaching, in the teaching of other subjects also showed a very serious problem, therefore should to innovation of teaching model, related personnel and units shall also be given highly attention to this problem.

Although at present university physical education teacher healthy body, energetic, but just have a natural quality cannot meet the requirements of educational reform under the new situation to ask, is difficult to keep up with The Times, the teacher knowledge structure of a single, teaching level is general, old method, etc. , which not only restricts the development of the teacher, but also reduces the teaching quality, and even some teachers professional ethics is not high, awareness is not strong, the work perfunctory, separation of the relationship between the teaching and education, there are individual sports teachers engaged in commercial activities, take teaching as a tool to earn money [3]. These phenomena on the one hand caused great negative influence to the student, on the other hand also blow the enthusiasm of the students' learning.

The teaching system to be perfect. College teaching system is not reasonable, because of the long historical reasons, many school football lesson teaching is to take on the "pan" phenomenon, ignoring the students individual differences, nor according to their aptitude, such making that weak 
foundation learn bad, basic good don't want to learn, eventually led to the overall level is not high, difficult to form theory and technology breakthrough [3]. And course arrangement is not reasonable, limited space for football, cannot accommodate several classes in physical education at the same time, a colleague in class, students of other class free activities, dampened the enthusiasm of students, this for both the school and will be unfavorable influence on students.

Students' enthusiasm is not high, football consciousness is weak. Students' sports football consciousness is weak, especially after entering the senior students to independent, mostly by what class students' decision for themselves, how to [3]. In the absence of teachers and parents, under the supervision of the majority of students during this time lost their direction, to oneself irresponsible, physical education classes is muddle along, or believes himself often play football at ordinary times as an excuse to not serious in class, understanding of football technology is impossible.

\section{Strategy analysis of College football teaching reform}

Set up the teaching idea of people-oriented. Campus football training is not only to teach players the related knowledge and professional skills, but also to help players get into the habit of exercise diligently, in the process, but also infiltration of moral education, cultivate the player's team spirit and cooperation consciousness and the fair competition consciousness, meet the diverse needs of players' preliminary development [4]. In the process of training, the coach needs to combine student's body and mind law of development, and through the football teaching, arouse students' interest in learning, in the process of football training throughout the humanistic ideas.

Develop players of football consciousness. Every footballer to be football consciousness, for the team's continued development plays a decisive role. Training football consciousness is a systematic project, need combined with the correct guidance of the coach, and after a long time of training and experience, and gradually form a football consciousness. In football teaching, coaches need in all aspects, and promote the comprehensive quality of adolescents to get comprehensive, laying the foundation of the cultivation of football consciousness [4]. The coach needs to provide opportunities for the competition of players, player's experience, make the player through the actual combat, to consolidate their knowledge and skills. Coaches need to create a good learning atmosphere, improve the level of the player's movement.

Establishing equal relationship between teachers and students. The teaching quality of the key factors is the relationship between teachers and students, coaches need to fully understand the player's ability and level, and to their personality and hobbies and so on to fully understand, create harmonious and equal relationship between teachers and students [4]. As a result, players need to be more to listen to the wisdom of the coach, and can become more active and initiative in the middle of the football training. Coaches when explains the concept of action, and a description of the language to be accurate, vivid and image, language should be enough to help the players better understanding, further to grasp of behavioral essentials, build a relaxed teaching atmosphere, causes the student to soccer practice can always stay motivated.

Optimization of football teaching and training. Choose specific teaching methods need to combine the teaching objectives and teaching tasks, college football face is mainly young people, in the teaching process, the coaches mainly use guidance and inspiration, cultivate the students' initiative and innovation spirit, guides the student to form the reflection ability, can accurately grasp their own football level [5]. In the actual teaching process, can use a variety of teaching methods, make students for increasing knowledge and understanding of the concept of ability, in the process of teaching, combined with the game, shooting, etc all kinds of sports, make the athlete's actual combat ability greatly been improved. In the actual teaching process, the football coach need to cultivate students' innovative spirit and thinking ability, teachers need to be teaching content fully excavated, cultivate students' problem consciousness and innovative spirit.

Strengthen the teacher's troop construction of their own quality. Without a high level of sports teachers, there is no high level of physical education teaching. As a new form of football teachers must improve their teaching level, improve their ability to complete the teaching mission, strengthen their own professional, outstanding athletic ability and organizational ability, combine 
teachers and education, establish good teacher among the schoolmates [5]. But also change their knowledge structure, master the basic knowledge of sports related, such as sports biochemistry, human genetics, human body structure, etc. Sports teacher should also constantly promote teaching achievements, break the traditional teaching mode, constantly breakthrough and innovation in the sports teaching, in the aspect of teaching monarchs alone thin diameter, awareness of sports and to stimulate students' interest, thus improve the teaching quality of football.

Strengthen the football course construction, talk about performance evaluation. Should not stay in football teaching just let the students master the skill movements of a few simple level, should let the students more flexible use of technology, from the game to improve their physical quality, cultivate team spirit and willpower, etc. , should also learn to appreciate the football match at the same time, a sense of beauty and happiness to football [6]. But the student is easy to credits, tests for gym class. Influenced by high-tech, few students like sports; atrophy of motor function, to make students experience the fun of the movement is very difficult. In view of the situation now, in football teaching, to recover the student's general physical quality as the foundation, to football practice, students can better control the football. Grades should be in the learning process and do not take the learning effect, reflect more the level the process of learning, weaken the color.

Refine the football teaching purpose, humanized teaching. Football, because of the large participation more than the number of students, sites, therefore, each player has a relatively fixed position and the division of labor [6]. For each position to the technical characteristics of the physical conditions are physical quality and different requirements. Through solicit opinions from the students, according to the student's own conditions, with the demand match; the students according to different position can be divided into forward, avant-garde, defender, goalkeeper etc. Several teaching team, with specific skills and tactics teaching is respectively [6]. Can also let the students in the process of game real refereeing practice, achieve the combination of theory and practice, make the teaching more purposeful and more refined, more conducive to the students' personalized development, give full play to the potential of students. Attaches great importance to the process and methods in teaching, pay attention to students' emotion, attitude and values, and guarantee the students' subjectivity, extensive and comprehensive and humanized set football teaching system [6]. To satisfy the college students' physical and mental health development, the principle of subjectivity embodied in, break through the traditional teaching methods, combining the fun of football and athletics, and by applying the method of class inside and outside integration, games, multimedia teaching method and so on has the teaching patterns and methods of modern education concept. To ensure the continuity of the college football study, to be based on the college football exercise habits, the concept of lifelong football training.

More efforts to develop football teaching resources. Colleges and universities to carry out should implement the spirit of the relevant documents of ministry of education, increase investment in football teaching funds, promote the construction of football stadiums and sports facilities, create conditions meet the practical requirement of football course construction as much as possible [7]. To strengthen the teaching of modern education technology, methods and content development and utilization, as an effective tool of football teaching is multimedia technology. To strengthen the construction of sports teachers and provide favorable conditions to attract based firm, the high quality of football teachers, to the position of teacher education, learning, further education after provide policy support, scientific research and academic exchanges.

Reasonable choose the teaching content. Improve the quality of football teaching needs the joint efforts of many sided, teacher's role is crucial, the teacher is responsible for the reasonable choice of teaching content, so should fully understand the situation of the students' study purpose and study, combines the condition of different reasonable choice [7]. You first need to know the purpose of students' football, is in order to keep fit or want to football as a profession, according to the different needs of the different ways of teaching content and training [7]. In addition, there are also different students' ability of learning to a large extent, on the basic level is good, strong learning ability of students should be arranged with a certain difficulty of learning content, to improve the control ability, for the poor foundation of poor students, ability to learn, have also shall arrange some relatively 
simple learning content, so it can within the scope of their abilities to complete the study content, not only won't be able to stimulate students' interest in learning, students can learn more knowledge and skills. Therefore, teachers should have a more full understanding to the student, on this basis for students to choose the most suitable teaching content, to improve the teaching quality of football it is very important.

\section{Summary}

Innovation type teaching is a teaching concept to today's very advocate, because innovation of any country in the field of development and the nation's overall development is very important. Innovation type teaching in the application of the football teaching in college and universities, the traditional football teaching there are some deficiencies, apply innovative teaching which is benefit to the improvement of teaching quality of football.

\section{Acknowledgements}

The Subject Construction Dual-support Plan of 2016.

\section{References}

[1] About the present situation and the analysis of football sports in colleges, Sports scientific literature, 2009, vol.12, pp.23-26.

[2] L. B. Yang, Football teaching present situation and the development countermeasure research, Journal of Chengdu sports institute, 2004, vol.9, pp. 12-14.

[3] Y. F. Xie, Football game in the football teaching application value analysis and discussion, stationary and science and technology, 2014, vol. 5, pp. 15-19.

[4] Zh. H. Huang, Football games in the teaching of college football reasonable application, The contemporary sports science and technology, 2013, vol. 5, pp. 12-15.

[5] X. T. Ma, Modern football sports advanced tutorial, Beijing: higher education press, 2002, vol. 3, pp. 14-16. .

[6] Y. X. Qin, Soccer technique and tactics teaching research, The day in the journal, 2007, vol. 12, pp. 65-67. .

[7] B. W. Cai, Introduction to fasten the ordinary university football teaching and training, Journal of Jilin institute of sport, 2009, vol.4, pp.61- 64 . 